\title{
Author Correction: Cellular deconvolution of GTEx tissues powers discovery of disease and cell-type associated regulatory variants
}

\author{
Margaret K. R. Donovan, Agnieszka D’Antonio-Chronowska, Matteo D’Antonio (D) \& Kelly A. Frazer (D)
}

Correction to: Nature Communications https://doi.org/10.1038/s41467-020-14561-0, published online 19 February 2020.

The original version of the Supplementary Information associated with this Article included incomplete Supplementary Data files 19, $20,21,23,24$, which did not include the full cell-type composition statistics. The HTML has been updated to include expanded versions of Supplementary Data 19, 20,21, 23, 24; the original versions of Supplementary Data 19, 20, 21, 23, 24 can be found as Supplementary Information associated with this Correction.

Published online: $\mathrm{xx}$ xxx 2020

\begin{abstract}
(c) Open Access This article is licensed under a Creative Commons Attribution 4.0 International License, which permits use, sharing, adaptation, distribution and reproduction in any medium or format, as long as you give appropriate credit to the original author(s) and the source, provide a link to the Creative Commons license, and indicate if changes were made. The images or other third party material in this article are included in the article's Creative Commons license, unless indicated otherwise in a credit line to the material. If material is not included in the article's Creative Commons license and your intended use is not permitted by statutory regulation or exceeds the permitted use, you will need to obtain permission directly from the copyright holder. To view a copy of this license, visit http://creativecommons.org/licenses/by/4.0/.
\end{abstract}

(C) The Author(s) 2020 